\title{
Development of competency assessment at attitude based on teaching Ki Hadjar Dewantara in elementary and middle school
}

\author{
Yuli Prihatni *, Supriyoko Supriyoko, Rahmatang Rahmatang \\ Universitas Sarjanawiyata Tamansiswa. Jalan Kusumanegara No.157, Muja Muju, Umbulharjo, \\ Yogyakarta, 55165, Indonesia \\ * Corresponding Author. E-mail: yuli_prihatni@ustjogja.ac.id \\ Received: 12 July 2018; Revised: 10 August 2018; Accepted: 9 October 2018
}

\begin{abstract}
This development research aims to (1) produce an attitude competency assessment model that is standardized based on the teachings of Ki Hadjar Dewantara, (2) Determine the attitude competency assessment indicators in elementary and secondary schools, (3) Determine the tendency of attitude competency of students in elementary and secondary schools. This research is a type of development research. The research was carried out in three provinces in Indonesia, namely DIY, Central Java and South Sulawesi. This research was conducted in three stages: pre-development, instrument development, and instrument testing. The subject of this study was 497 students in elementary and secondary schools. Content validity was analyzed using the Aiken Index, and construct validity was analyzed using exploratory factor analysis. The results of this study are (1) The compilation of affective attitude competency assessment models that are standardized based on Ki Hadjar Dewantara's teachings to realize noble character students. Research has succeeded in establishing attitude competency assessment indicators in elementary and secondary schools, including 6 indicators. (3) the tendency of Ngandel attitude to students in the subject try included in the High category, Kendel Aspect included in the High category, Bandel aspects included in the medium category and Kandel aspect included in the High category.
\end{abstract}

Keywords: assessment, attitude, Ki Hadjar Dewantara

How to Cite: Prihatni, Y., Supriyoko, S., \& Rahmatang, R. (2019). Development of attitude competency assessment test based on teaching of Ki Hadjar Dewantara in elementary and secondary school. Jurnal Prima Edukasia, 7(1), 1-8. doi:https://doi.org/10.21831/jpe.v7i1.21517

https://doi.org/10.21831/jpe.v7i1.21517

\section{Introduction}

Education aims not only to build human beings who are intelligent of a brain and skilled in carrying out tasks but also aims to produce humans who have noble and courtesy character. Therefore, education is not merely transferring knowledge to students, but also transfers universal of character values and human values. According to UNESCO in the Education for All Global Monitoring Report (EFA-GMR), The Education for All Development Index (EDI) presented in the UNESCO-UIS (2012) statistical table, Indonesia ranked on 57th out of 115 countries. Indonesia is still in the medium category, with an index value of 0.947 .

The implementation of education always relates to the curriculum. The curriculum has an influence on all educational activities; thus, the role of the curriculum become very important and the core of education. The curriculum is a tool to achieve educational goals, which is able to build value and behavior of students with noble character, having an order that can be accepted by all members of society, and behave well in line with the prevailing norms (Prihatni, 2016). In Law No. 20 of 2003 on National Education System, stated that the curriculum is a set of plans and arrangements on the purpose, content, and material of learning and the methods used as guidelines for the imple-mentation of learning activities to achieve certain educational goals. Today, the applicable curriculum in primary and secondary schools is curriculum 2013 (Presiden Republik Indonesia, 2003). At a time when educational goals have not been fully achieved, this is indicated by the many problems that arise related to misbehaving from the noble values of national culture and it is carried out by students 
Jurnal Prima Edukasia, 7 (1), 2019 -2

Yuli Prihatni, Supriyoko Supriyoko, Rahmatang Rahmatang

starting from the level of Elementary School (SD), high school, even students in Higher Education (PT). For example, many students of elementary and middle school already know cigarettes, drugs, and sex. They are free to interact without restrictions and ethics. Manners, respect for teachers, tepo sliro, have begun to begone. From time to time, the noble values began to fade, begone, lose their substantive meaning and seemed to be meaningless symbols.

Education is an effort to advance the character, mind, and body of children aiming to advance the perfection of life, which is life and revive children in harmony with nature and society (Dewantara, 2013, p. 26). Taman siswa education is carried out by sharpening daya cipta (conative), daya rasa (affective) and daya karsa (psychomotor) of humans.

Education at Tamansiswa implements the Among system; a system of education that is family-minded and has natural nature and independence. Then, in the system among, each pamong as a leader in the education process implement: Tutwuri Handayani, Ing Madya Mangun Karsa, Ing Ngarsa Sung Tuladha (Prihatni, 2014).

The education system of among puts children as central in the education process. The children are free to develop all the potential in line with the interests of talents. Therefore, it will emerge creativity, and the role of pamong as guidance; guide the students when they experience difficulties or need help (Prihatni, 2016). The education system of among based on how it applies called as the Tutwuri Handayani System.

Education is a guide of life for the growth of children (Muthoifin, 2015). According to Ki Hadjar Dewantara, education guides all the natural power within the children so that they as humans and as members of society can achieve safety and happiness as highest as possible (Dewantara, 2013, p. 20; Suwartiani, 2017). The Educational Concept of Ki Hadjar Dewantara is in line with Rabindranath Tagore, stated that the highest education is the things that not only give us information but also makes our lives harmonious with all existence (Kumar \& Ahmad, 2008).

Education can glorify life as stated by $\mathrm{Ki}$ Hadjar Dewantara in the 1st independent living fatwa "Lawan Sastra Ngesti Mulya" which means with our knowledge lead to glory or with knowledge achieved happiness/prosperity (Boentarsono, 2012). Thus, education and learning should provide in every aspect, which is not only emphasized cognitive/knowledge aspects but also consider the aspects of attitude. Attitude/ affective learning related to how students feel when they learn, as well as how learning experiences internalized so that they can guide students' attitudes, opinions and behavior in the future (Olatunji, 2013, p. 97).

Today, character education is best understood as a deliberate effort to promote the development of virtue, moral values, and moral agency in youth, especially in schools (Berkowitz \& Hoppe, 2009). Learning according to (Kek, Darmawan, \& Chen, 2007) is influenced by: (a) parents with low educational background, (b) parents show great interest for students' studies, (c) students' great personal beliefs in their competence in dealing with and managing challenging environmental demands, (d) students' positive perceptions are mainly characterized by students' shared, critical, and negotiation controls. The factors are also directly influenced by (e) high-level readiness of learning, and (f) mental health is indirectly as good.

Today, teachers in primary and secondary schools still have difficulty in conducting attitude assessments in learning, because there are no standardized instruments. Measuring the competency attitudes is different from measuring knowledge and skills competencies. The finding by Suryani (Asnita, 2014) stated that implementing cognitive, affective and psychomotor domains in assessment is not easy due to various factors, including (1) low commitment, (2) inadequate ability and knowledge; (3) limited facilities and supporting funds; (4) political will from among the central government, regional government and schools; and (5) less effective information dissemination. Assessment of attitudes is no longer the sole authority of the Guidance and Counseling (BK) teacher, but each teacher must provide tools and instruments of assessment that are representative, complicated, and comprehensive for potential attitudes and behaviors in supporting children's learning achievement. Thus, it is important to develop an attitude competency assessment using standardized instruments. Attitude assessment performs to gain feedback for either teachers or students as a basis for improving student behavior and reports to parents. Improvement of attitudes and behavior of students will succeed optimally if conduct together consistently among three aspects, which are family, school, and society.

The particular study aimed to (1) produce an attitude competency assessment model that is standardized based on the teachings of Ki Hadjar 
Jurnal Prima Edukasia, 7 (1), 2019 -3

Yuli Prihatni, Supriyoko Supriyoko, Rahmatang Rahmatang

Dewantara, (2) Determine the attitude competency assessment indicators in elementary and secondary schools, (3) Determine the tendency of attitude competency of students in elementary and secondary schools.

In Permendiknas (The Ministry Regulation of National Education) No. 20 of 2003 concerning the standard of assessment explained that the assessment is the process of collecting and processing information to determine the achievement of student learning outcomes (Presiden Republik Indonesia, 2003). According to (Aiken, 2003, p. 454) assessment is a personal characteristic by accessing human behavior and mental processes through observation, interviews, rating scales, check lists, projective techniques and tests. Assessment is an activity to determine the value/score of an object, such as good or bad, effective-ineffective, successfulunsuccessful, in accordance with the determined criteria or benchmarks.

The principle of assessment according to (Mardapi, 2017) must provide accurate information, encourage students to learn, motivate teachers in teaching, improve the performance of institutions and improve the quality of education. Assessment of affective aspects performed through observation and questionnaire. In general, attitude assessments can perform in line with attitudes towards certain objects, attitudes related to values that are to instill in students through a certain material, and attitudes related to effectiveness competency of cross-curriculum. The principles that must be considered by the teacher in carrying out the assessment for the implementation of the 2013 Curriculum both at the elementary education level (SD or elementary school/MI or Islamic elementary school) and at the secondary education level (SMP or junior high school/MTs or Islamic high school, SMA or senior high school/MA or Islamic high school and SMK or vocational high school/MAK or islamic vocational high school) are Sahih (accurate), Objective, Fair, Integrated, Open, Comprehensive and Continuous, Systematic, Reference Criteria, Accountable, and Educative.

\section{Method}

The research was research and development research (Gall, Gall, \& Borg, 2007). The research and development model is the process used to develop and validate products in the world of education. This research also often called "research-based development" which appears as a strategy to improve the quality of education. The research and development approach is deemed appropriate or suitable to be used in the development of this learning because the goal of this research is not merely to find an implementation profile or learning practices, but even more, which is to develop effective and adaptable learning models according to the real conditions and needs in school. The factor caused by this approach has advantages, especially viewed on the work procedures that consider the real needs and situations in school, systematic, and cyclical. This approach is different from educational research in common. Educational research more emphasis on discovering new knowledge or answering specific questions regarding practical problems in the field of learning, poor in terms of methodologies for developing new learning products that are truly able to use in schools, and ignoring the field conditions and situations.

The particular research conducted in three stages, namely: pre-development, instrument development, and instrument testing. The detailed research stages were: (1) Literature study conducted by examining theories about attitude assessment according to teachings of Ki Hadjar Dewantara with ngandel, kendel, bandel, and kandel aspects; (2) Compile the draft of the product by compiling the instructions of instruments on attitude competence of ngandel, kendel, bandel and kandel aspects; (3) Focus Group Discussion (FGD) conducted by examining the drafts to experts of ketamansiswaan, measurement experts, education experts, grammar experts, and education council; (4) The prototype model is the making a model based on the development of instrument instruction as the results of focus group discussion (FGD); (5) Model trials carried out at the primary and secondary education levels in the provinces of Central Java, Yogyakarta Special Region, and South Sulawesi; (6) Extended trials conducted at the level of primary and secondary education in the provinces of Central Java, Yogyakarta Special Region, and South Sulawesi. The trial conducted to 9 (nine) schools. The trial used the attitude competency assessment model based on the teachings of Ki Hadjar Dewantara with 96 items consisting of 48 valence items and 48 factual items; (7) Data analysis carried out by exploratory factor analysis and data evaluation of student attitude carried out descriptively; and (8) Interpretation conducted based on the results of data analysis. 
Jurnal Prima Edukasia, 7 (1), 2019 -4

Yuli Prihatni, Supriyoko Supriyoko, Rahmatang Rahmatang

Research in the first year carried out in three provinces; Yogyakarta Special Region, Central Java, and South Sulawesi Province. In detail, the research subjects are presented in Table 1.

Table 1. Research Subjects

\begin{tabular}{cclc}
\hline No. & Provinces & \multicolumn{1}{c}{ Schools } & $\begin{array}{c}\text { Total of } \\
\text { Sample }\end{array}$ \\
\hline 1. & Central Java & SD N Prambanan 1 & 65 \\
& & SMP N 02 Kajoran & 50 \\
2. & Yogyakarta & SMK N 7 Purworejo & 64 \\
& Special & SMP Taman Muda & 21 \\
& Region & Cendekia & 51 \\
& & SMA N 1 Semanu & 44 \\
3. South & SD Inpres & 74 \\
& Sulawesi & Mannuruki 1 & 64 \\
& & SMP N 3 Makasar & 64 \\
& & SMA N 16 Makasar & 64 \\
\hline
\end{tabular}

Data collection techniques used attitude competency questionnaires according to $\mathrm{Ki}$ Hadjar Dewantar concept and interviews. Data analysis used exploratory factor analysis. Factor analysis studies that seek to simplify the number of variables from a study into hypothetical variables which are fewer in number but contain meaning. The main principle of factor analysis is the correlation. So, it required assumptions that related to the correlation, namely: Correlation between independent variables $>0.5$ with significance $<0.05$; Partial correlation in Anti Image Correlation> 0.5 ; and Testing all correlation matrices (correlation between variables) measured by Bartlett's Test of Sphericity or Measure of Sampling Adequacy> 0.5.

\section{Results and Dicsussion}

Learning according to teachings of $\mathrm{Ki}$ Hadjar Dewantara is a learning process using the Among System. The system of among is a system with family spirit nature-based and independence. Student-centered learning uses various sources, methods and learning media; teachers are as pamong (tutors) with asah-asih-asuh (educating, loving and guiding), giving assignments supporting students' creativity, not distinguish students based on ethnicity, religion, and race. In the learning, the teacher must apply Ing Ngarso sung Tuladha, Ing Madya mangun Karsa, and Tut Wuri Handayani. The development model of attitude competency assessment according to teachings of Ki Hadjar Dewantara conducted in schools and was marked by the following indicators.
The implementation of the Tamansiswa Teachings in schools include: (1) Schools in implementing education involve Tri Education Centers (Family/Parents, Schools, and Communities). (2) Schools establish cooperation with various parties based on the TriKo principle (Cooperative, Consultative, and Corrective). (3) Education sharpens Cipta-Rasa-Karsa (Cognitive, Affective, and Conative).

The implementation of Tamansiswa teachings in learning ie applies learning using the Among system, which is a family-minded system based on nature and independence. They are: (1) Student-centered learning. (2) Learning uses various sources, methods and learning media. (3) Teachers as tutors are pamong with asah-asihasuh (educating, loving and guiding). (4) The teacher provides assignments supporting student creativity. (5) The teacher does not distinguish students based on ethnicity, religion, and race. (6) In the learning, the teacher must apply Ing Ngarso sung Tuladha, Ing Madya mangun Karsa, and Tut Wuri Handayani. (7) Learning applies the "Tri N" approach: Niteni, Niroke, and Nambahi, and (8) Learning applies the concepts of "Tri Ngo" (Ngerti, Ngrasa, and Nglakoni) (Cognitive, Affective and Psychomotor).

Competency Assessment Attitudes in this study include: Ngandel-Kendel-Bandel-Kandel. Ngandel is an attitude and behavior that reflects trust within self/Self-Confidence, with confidence, Optimism, Rational, responsible, and realistic. Kendel is an attitude and behavior that reflects courage because it is true, honest, mature thinking before acting, disciplined, big-spirited and ready to take risks/obedience (orderly) and dare to be different from others (creative). Bandel is an attitude and behavior that is resilient / not easily discouraged, diligent, full of enthusiasm, tenacious and tawakal.

Kandel is a thick attitude and behavior on religion faith (religiosity), tolerance, empathy, gratefulness, tolerance and having a high concern for others. The development model of attitude competency assessment according to teachings of Ki Hajar Dewantara is presented in Figure 1.

The next step after literature study on the teachings of Ki Hadjar Dewantara in the process of developing a standardized attitudes competency assessment model, it carries out developing an assessment model through instruction that arranged according to concepts, indicators, coding on valence and factual data both positive and negative and the number of items. 
Jurnal Prima Edukasia, 7 (1), 2019 -5

Yuli Prihatni, Supriyoko Supriyoko, Rahmatang Rahmatang

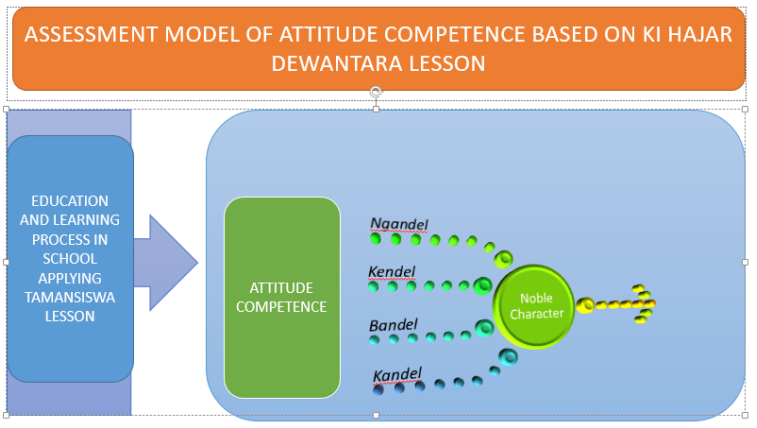

Figure 1. Model of attitude competency assessment according to teachings of Ki Hajar Dewantara

In developing the competency assessment model of the kendel attitude, there are 4 (four) aspects of attitude according to teachings of $\mathrm{Ki}$ Hadjar Dewantara, namely;

\section{Ngandel}

Table 2. Indicators of Ngandel Aspect

\begin{tabular}{cl}
\hline \multicolumn{1}{c}{ Aspect } & \multicolumn{1}{c}{ Indicators } \\
\hline Ngandel & Responsible \\
& Confident \\
& Optimistic \\
& Self-confidence \\
& Rational \\
& Realistic \\
\hline
\end{tabular}

Kendel

Table 3. Indicators of Kendel Aspect

\begin{tabular}{cl}
\hline \multicolumn{1}{c}{ Aspect } & \multicolumn{1}{c}{ Indicators } \\
\hline Kendel & Great Soul \\
& Honest \\
& Creative \\
& Independence \\
& Order/Discipline \\
& Brave \\
\hline
\end{tabular}

Bandel

Table 4. Indicators of Bandel Aspect

\begin{tabular}{ll}
\hline \multicolumn{1}{c}{ Aspect } & \multicolumn{1}{c}{ Indicators } \\
\hline Bandel & Hard Work \\
& Spirit \\
& Tawakal \\
& Diligent \\
& Not easily discouraged \\
& Tenacious \\
\hline
\end{tabular}

Kandel

Table 5. Indicators of Kendel Aspect

\begin{tabular}{cl}
\hline \multicolumn{1}{c}{ Aspect } & \multicolumn{1}{c}{ Indicators } \\
\hline Kandel & Grateful \\
& Empathy \\
& Care \\
& Religious \\
& Respect each other \\
& Tolerance \\
\hline
\end{tabular}

From 4 (four) aspects, it then developed into an instruction of attitude competency assessment models according to teachings of $\mathrm{Ki}$ Hadjar Dewantara consisting of 48 valence items and 48 factual items. After the instructions and items of the assessment model completed, a draft product review conducted and consulted with the expert judgment through a focus group discussion where experts and practitioners examined and provided input for the improvement of the model. The attitude competency assessment model according to teachings of $\mathrm{Ki}$ Hadjar Dewantara compiled based on 4 (four) aspects of attitude competencies as outlined in the instruction.

Based on the instruction, an assessment model was made in the form of the questionnaire with 96 items consisting of 48 valence items (attitude) and 48 factual items (behavior), where each of them consisted of 24 positive points and 24 negative points. The scale of the instrument used a Likert scale with 4 alternative answers with a score of 1 to 4 . Aiming to measure the attitude competency according to teachings of $\mathrm{Ki}$ Hadjar Dewantara was through an attitude scale that functions expressively and valence items have a correlation with factual items that express attitudes and behaviors and reflect the attitude competency values according to teachings of $\mathrm{Ki}$ Hadjar Dewantara. The compiled instruments are validated by the expert judgment at the focus group discussion (FGD). The final FGD results were used by researchers to improve the instruments. After revised, it continued to trial to 497 students in Central Java, Yogyakarta, and South Sulawesi. Then, factor analysis was carried out. The value of Kaiser Meyer Olkin (KMO) and Bartlett's Test for the correlation between the desired variables is $>0.5$ with the significance of the study $<0.05$. Based on the results of the analysis, it obtained a KMO value of 0.880 which means $>0.5$ and the significance by Bartlett's Test of Sphericity is 0,000 , which means $<0.005$. All MSA values by observing the diagonal lines of the Anti-image correlation marked with letters a> 0.5 . Data communalities showed the high (\%) the factors in explaining the item variance. The item stated having a strong relationship with the formed factors if it has a value $>0.5$. The items of attitude competency assessment model according to the teaching of Ki Hadjar Dewantara of 96 items have a value of $>0.5$. The Eigenvalues are observed in the table of Total Variance Explained. In initial Eigenvalues showed the formed factor while Extraction Sum of Squared Loading 
showed the number of variants obtained. In the development of this assessment model, it formed 25 factors and 25 variants. The total of 25 factors explains the variable at $61,400 \%$. Because the Comunalitive number is $>60 \%$, the formed factors are sufficient. The form of a scree plot used to determine the number of factors formed by 25 factors.

The loading factor of the Rotated Component Matrix showed that all items have a factor load. The highest correlation showed that the variable appropriate more in the Component Matrix. The results of the analysis after showing rotation carried out; all items had a factor load where 96 items of assessment instruments were spread over 25 factors. Then, the final step was performed by compiling the instrument into the final assessment model and implemented to measure the attitude competency according to teachings of Ki Hadjar Dewantara. The reliability test results obtained Cronbach's Alpha value of $0.928 \geq 0.5$ which means 96 items were reliable.

Based on the data, the mean for attitude competency score according to the teaching of $\mathrm{Ki}$ Hadjar Dewantara was 292.72. The mean is 288.00 - 312.00, which means scoring attitudes are in the High category $(\mathrm{T})$. The results are presented in histograms in Figure 2.

Histogram

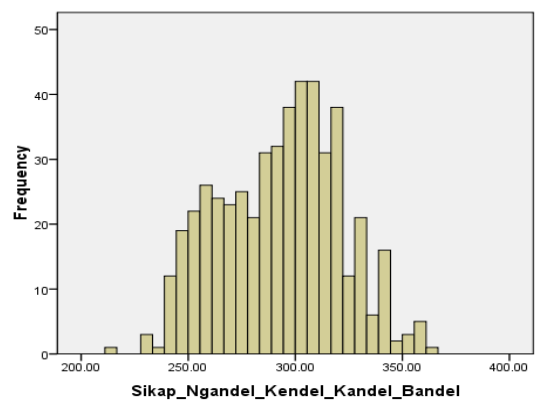

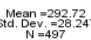

Figure 2. The Histogram of Attitude

Competency Score According to the Teaching of Ki Hadjar Dewantara

Based on the data, the mean for the "Ngandel" attitude value is 73.46. The mean is 72.00-78.00, which means the "Ngandel" attitude is in the High category (T). The results are presented in histograms in Figure 3.

Based on the data, the mean for the "Kendel" attitude value is 73.46 . The mean is 72.00-78.00, which means the "Kendel" attitude is in the High category $(\mathrm{T})$. The results are presented in histograms in Figure 4.

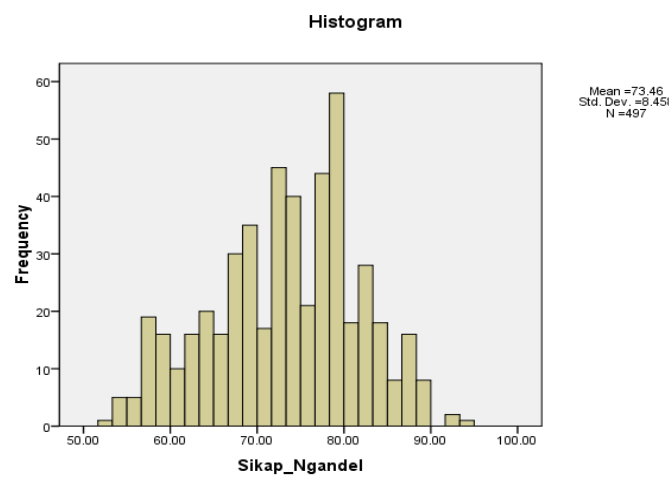

Figure 3. The Histogram of Ngandel Attitude Competency Score According to the Teaching of Ki Hadjar Dewantara

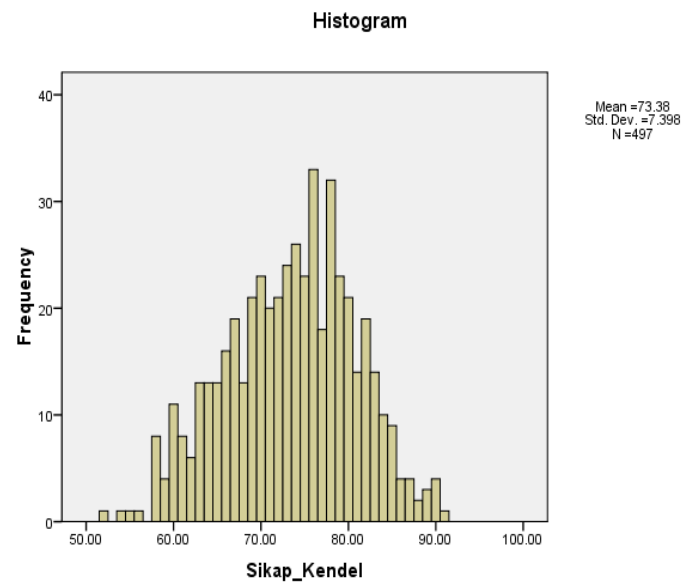

Figure 4. The Histogram of Kendel Attitude Competency Score

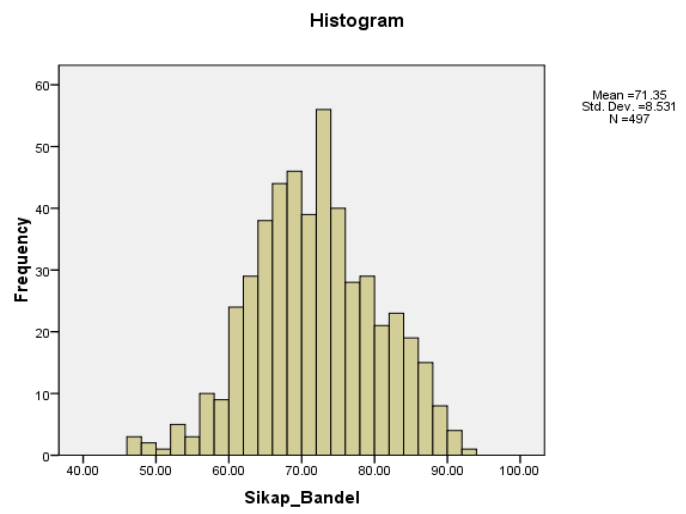

Figure 5. The Histogram of Bandel Attitude Competency Score

Based on the data, the mean for the "Bandel" attitude value is 71.35 . The mean is 54.00-72.00, which means the "Bandel" attitude is in the Medium category (Sd). The results are presented in histograms in Figure 5.

Based on the data, the mean for the "Kandel" attitude value is 74.53. The mean is 72.00-78.00, which means the "Kandel" attitude 
is in the High category (T). The results are presented in histograms in Figure 6.

Histogram

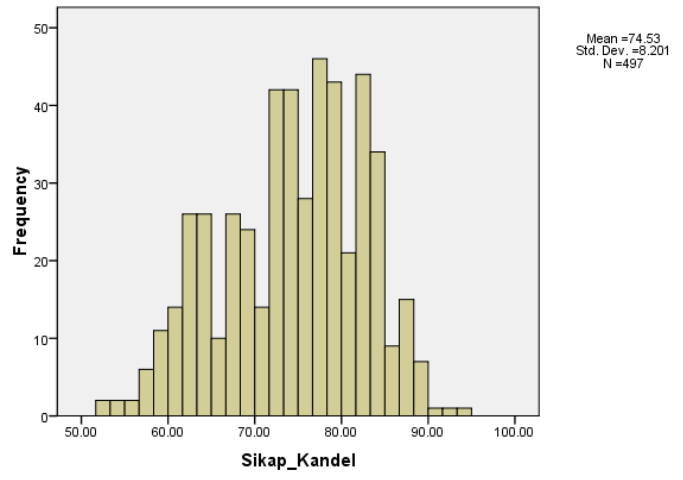

Figure 6. The Histogram of Kandel Attitude Competency Score

Based on the results, generally, the mean for scoring the implementation of learning according to teachings of Ki Hadjar Dewantara represented by teachers at the elementary and secondary education levels in the provinces of Central Java, Yogyakarta Special Region and South Sulawesi to 76 teachers is 26.01 . The mean is in between 26.00 and above, and the means is in a very well implemented category.

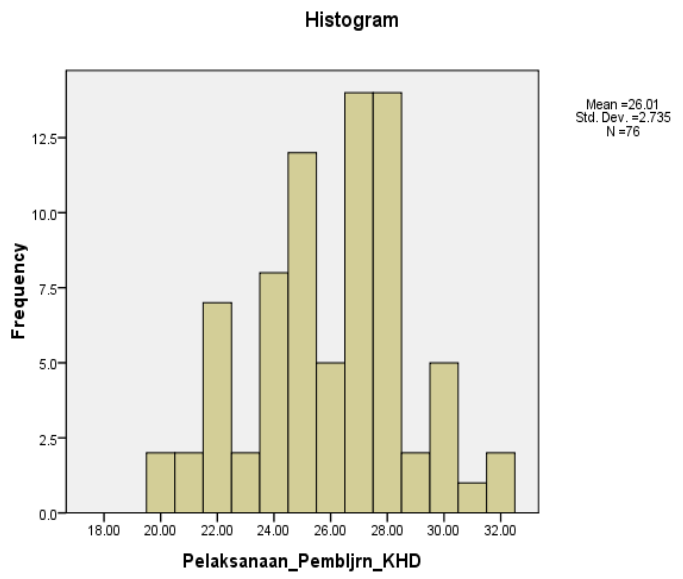

Figure 7. The Histogram of Learning Implementation according to teaching of $\mathrm{Ki}$ Hajar Dewantara

The results of attitude competency tendencies in the aspects of ngandel, kandel and kendel are in the high category and the bandel aspects are in the medium category. When associated to the teachings of Ki Hadjar Dewantara that the teacher must able to give and be an example of students (Ing Ngarsa Sung Tuladha), then the attitude of the students is inseparable from how the teacher educates the students. In line with (Astuti, Haryanto, \& Prihatni, 2018;
Fathurrohmah, 2017; Setiawan \& Astuti, 2018) stated that the tendency of understanding the pamong to curriculum and learning methods are independent in line with teachings of Ki Hadjar Dewantara in the high category.

\section{Conclusion}

The particular development research has produced a standardized attitude competency assessment model according to the teachings of Ki Hadjar Dewantara to realize students with noble character, including aspects of Ngandel attitude (Self-Confidence); Kendel (Dare because right); Bandel (Not easily discouraged / Tough); and Kandel (Full of Faith) which each of aspects consisted of 6 indicators. The tendency of Ngandel Attitude (Self-Confidence) of students in the trial subject is in the category of High. Kendel Aspects (Dare because Right) included in the category of High. Bandel aspects (Not Easily Discouraged/Tough) included in the medium category. And, Kandel aspects (Full of Faith) included in the High category.

\section{References}

Aiken, L. R. (2003). Psychological testing and assessment. Allyn and Bacon.

Asnita, Y. (2014). Pengembangan instrumen penilaian afektif. Jurnal Evaluasi Pendidikan, 7(1), 61-67. https://doi.org/10.21009/JEP.071.07

Astuti, D. A., Haryanto, S., \& Prihatni, Y. (2018). Evaluasi implementasi kurikulum 2013. Wiyata Dharma: Jurnal Penelitian Dan Evaluasi Pendidikan, 6(1), 7-14. https://doi.org/10.30738/WIYATA DHARMA.V6I1.3353

Berkowitz, M. W., \& Hoppe, M. A. (2009). Character education and gifted children. High Ability Studies, 20(2), 131-142. https://doi.org/10.1080/135981309033584 93

Boentarsono, K. B. (2012). Buku saku: Tamansiswa badan perjuangan kebudayaan \& pembangunan masyarakat. Yogyakarta: Perguruan Tamansiswa.

Dewantara, K. H. (2013). Pemikiran, konsepsi, keteladanan, sikap merdeka I (Pendidikan). Yogyakarta: UST Press \& Majelis Luhur Persatuan Tamansiswa.

Fathurrohmah, T. (2017). Pengembangan instrumen pengukuran sikap proaktif siswa SMA Negeri 1 Klirong Kebumen. Wiyata Dharma: Jurnal Penelitian Dan Evaluasi 
Jurnal Prima Edukasia, 7 (1), 2019 -8

Yuli Prihatni, Supriyoko Supriyoko, Rahmatang Rahmatang

Pendidikan, https://doi.org/10.30738/WIYATA

DHARMA.V5I2.3384

Gall, M. D., Gall, J. P., \& Borg, W. R. (2007). Educational research: An introduction. Boston: Pearson/Allyn \& Bacon.

Kek, M. Y. C. A., Darmawan, I. G. N., \& Chen, Y. S. (2007). Family, learning environments, learning approaches, and student outcomes in a Malaysian Private University. International Education Journal, 8(2), 318-336.

Kumar, S., \& Ahmad, S. (2008). Meaning, aims and process of education. School of Open Learning. https://doi.org/DOI: 10.1080/13598130903358493

Mardapi, D. (2017). Pengukuran penilaian dan evaluasi pendidikan. Yogyakarta: Nuha Medika.

Muthoifin, M. (2015). Pemikiran pendidikan multikultural $\mathrm{Ki}$ Hadjar Dewantara. Intizar, 21(2), 299-320. Retrieved from http://jurnal.radenfatah.ac.id/index.php/int izar/article/view/314

Olatunji, M. O. (2013). Teaching and assessing of affective characteristics: A critical missing link in online education. International Journal on New Trends in Education and Their Implications, 4(1), 96-107. Retrieved from
http://www.ijonte.org/FileUpload/ks6320 7/File/09.olatunji.pdf

Presiden Republik Indonesia. Undang-Undang Republik Indonesia nomor 20 tahun 2003 tentang sistem pendidikan nasional, Pub. L. No. 20, Undang-Undang Republik Indonesia 26 (2003). Indonesia.

Prihatni, Y. (2014). Pendekatan saintifik dalam ajaran Ki Hadjar Dewantara. In Prosiding Seminar Nasional Pendidikan Sains. Yogyakarta: Universitas Sarjanawiyata Tamansiswa.

Prihatni, Y. (2016). Pendidikan Tamansiswa dan relevansinya dalam menjawab permasalahan pendidikan di Indonesia. Yogyakarta.

Setiawan, A., \& Astuti, W. (2018). Development of children's anxiety test special needs. In PROCEEDING INTERNATIONAL SEMINAR ON EDUCATION (Vol. 0). Retrieved from http://jurnal.ustjogja.ac.id/index.php/dpsp 2018/article/view/3232

Suwartiani, S. (2017). Metode index card untuk meningkatkan hasil belajar. Jurnal Pendidikan: Riset Dan Konseptual, 1(1), $1-6$.

https://doi.org/10.28926/riset_konseptual. v1i1.1 